\title{
Russian Gas Companies Strategies in the Asia-Pacific and in the Arctic under Western Sanctions and Selective Government Support
}

\author{
Sergei Sevastianov ${ }^{1} \&$ Ekaterina Sokolova $^{2}$ \\ ${ }^{1}$ International Relations Department, Far Eastern Federal University, Vladivostok, Russia \\ ${ }^{2}$ Maritime State University Named after Admiral Nevelskoy, Vladivostok, Russia \\ Correspondence: Sergei Sevastianov, International Relations Department, Far Eastern Federal University, \\ Sukhanova 8,690091, Vladivostok, Russia. Tel: 8-984-158-7001. E-mail: sevastyanov.sv@dvfu.ru
}

Received: October 28, 2019

Accepted: November 24, 2019

Online Published: January 29, 2020

doi:10.5539/jpl.v13n1p66

URL: https://doi.org/10.5539/jpl.v13n1p66

\begin{abstract}
The main purpose of this research is to determine whether Russia being under Western economic sanctions could significantly strengthen its presence in the Asia-Pacific with a pipeline gas and LNG supplies. Based on the study of the Russia's current and planned gas projects in the eastern part of the country and in the Arctic, that are realized under sanctions' pressure, the authors concluded that most probably by 2030 Moscow can reach this strategic objective. To resist Western sanctions against the Russian energy industry Moscow launched a program of accelerated import substitution, and as a result they have only partially achieved their goals. Considering Russia's largest gas exporters, they resorted to different strategies to counter sanctions. The state company Gazprom postponed plans for offshore gas exploration in the Arctic and continues to prioritize gas pipeline projects which reinforce its dependence on China. In contrast, with the help from the RF government and foreign investors, the private company Novatek successfully creates a powerful infrastructure for producing LNG in the Arctic and for delivering it to Europe and the Asia-Pacific.
\end{abstract}

Keywords: Gazprom, Novatek, Russian gas exports to Northeast Asia, Western sanctions against Russian energy industry

\section{Introduction}

Between 2015 and 2035 Russia plans to increase its gas supply to the Asia-Pacific region (APR) by 9 times from $14 \mathrm{bcm}$ in 2015 to $128 \mathrm{bcm}$ in 2035 (Energy Strategy, 2015). Therefore a significant number of new gas projects aims to expand the Russian presence in the Northeast Asia (NEA) market. This strategic task is facilitated by such factors, as: China, Japan and the Republic of Korea (RK) currently are the largest natural gas consumers in East Asia; steady growth in gas demand from China; the availability of significant capital and the high level of technology development of NEA countries, etc. The latter is particularly relevant for Moscow in the context of Western financial and technological sanctions imposed against Russia since 2014 (after Crimea became part of its territory and the beginning of conflict in eastern Ukraine).

Existing literature on the place of Russia in the NEA gas market has for a long time reflected two opposite approaches. The "skeptical" one proceeded from the argument that demand for natural gas in NEA will not grow, while Moscow will be less competitive in terms of gas suppliers due to the lack of access to Western capitals and technologies (Blank, Kim 2014). As for the Arctic, some experts have predicted that due to Western sanctions, Russian gas projects in the Arctic are doomed to failure (Baev, 2015; Kapyla, Mikkola, Martikainen, 2016 and others). The second approach can be described as "positive" and is based on the assumption that demand for natural gas in NEA will grow, mainly to China, and taking this into account experts from NEA, for example, in China (Shi, 2015) and Japan (Motomura, 2014) have given a positive assessment of the prospects for Russian gas exports to the region.

Novatek's success in launching the first LNG plant in the Arctic in 2018 changed the tonality of the discussion on the prospects of Russian gas in NEA for a more nuanced one. For example, a Special Report in 2018 charted the development of energy interaction between Russia and the APR countries (Downs, Henderson, Herberg, et. al, 2018). According to it, with the advent of an ambitious gas company such as Novatek, and with substantial financial support from China, "Russia has withstood the pressures of the simultaneous drop in oil prices and 
Western sanctions far better than most analysts expected". Another expert noted that Moscow has managed to successfully pursue its energy goals, despite the negative impact of sanctions on other areas of the Russian economy (Coote, 2018).

In 2019, it became clear that US and EU financial and technological sanctions, aimed at eliminating access to Western capital markets and new technologies for Russian oil and gas companies, would be expansive and long lasting. At the same time, international gas flows in the APR are set to transform due to the fast progress of Novatek in the Arctic, thus the assessment of whether Russia can become a significant supplier of gas to NEA in the face of the Western sanctions is a pressing scientific and practical issue.

The Energy Strategy of the Russian Federation up to 2035 assumes that the main growth in energy demand will occur in the APR (Energy Strategy, 2015). This growth would justify the projected two new gas pipelines to China (Vatansever, 2017) and opens up new opportunities for the export of Russian gas, but requires large investments in the development of production and transportation infrastructure. According to the document, Russia should significantly strengthen its presence in the APR with a pipeline gas and LNG supplies. To fulfill the Energy Strategy goals, Russia plans:

- to accelerate the development of gas resources in traditional and new (Yamal and Gydan Peninsulas, Eastern Siberia and Far East) regions on the basis of advanced (mostly domestic) technologies;

- to diversify gas exports and significantly (by 5 - 9 times) increase natural gas supply to the APR brining it by 2035 to $75-135 \mathrm{bcm}$ (of them 64-115 bcm to NEA).

In this research the authors will try to determine the attainability of these goals by the Russian gas companies under long-term Western sanctions by engaging with the following key research tasks:

- to evaluate Russia's existing and future projects for the extraction and transportation of gas in NEA in terms of likely gas production volumes and probability of their execution on schedule, taking into account the impact of anti-Russian financial and technological sanctions;

- to clarify the impact of those sanctions on the gas production strategies and capabilities of Russia's leading gas companies (Gazprom and Novatek) in the APR and in the Arctic, and the countermeasures they have taken.

\section{Method}

To achieve these tasks, as key research methods the authors used modeling and analysis of alternative scenarios, as well as such fundamental to political science method as a comparative. To predict Russian gas companies (Gazprom and Novatek) projects' perspective based on the analysis of the possibilities and risks (in international politics, financial, technological and other spheres), defining Russian gas export to NEA, they analyzed and modeled alternative scenarios for their planning and realization. It is also justified by the fact that these companies are often proposing gas export projects that compete with each other (or are even mutually exclusive), because they rely on the same deposits, assume to use the same gas transportation system, or are competing for limited government preferences and finances.

To study the essence and specific features of the gas producing and exporting strategies to which Gazprom and Novatek resorted in the Arctic and in the eastern part of the country, and the countermeasures they have taken against Western economic sanctions, the authors widely used the comparative method. Besides, they relied on such methods as: quantitative and qualitative analysis of open statistical and other sources; calculations and projections, etc.

\section{Results}

\subsection{Current Gas Production in the Russian Far East (RFE) and in the Arctic}

Russian gas export to NEA started in 1990s, when under the production sharing agreements two projects had been realized: Sakhalin-1 and Sakhalin-2. The Sakhalin-1 consortium members are: the project operator American company Exxon Neftegas Limited (30\%), Russian Rosneft (20\%), Indian ONGC (20\%) and Japanese SODECO (30 \%). Potential gas production at Sakhalin-1 is estimated at 10-12 bcm, but consortium does not have own LNG plant and also could not export gas, due to monopoly of Gazprom on gas pipeline export in Russia. Gazprom has a controlling stake in the Sakhalin-2 project (50\% plus one shares), Royal Dutch Shell $-27.5 \%$ minus one shares, Japan's Mitsui - $12.5 \%$, Japan's Mitsubishi - $10 \%$. After commissioning in 2009 of the first LNG plant in Russia, average annual production of LNG from this project has been about 11.5 $\mathrm{mt}$, and practically all of it goes to NEA.

In 2014 Russia and China signed an important contract which provides for delivery of gas from Chayanda field in the Republic of Yakutia to China through the Power of Siberia pipeline for 30 years. First gas deliveries by 
this pipeline began in December 2019, and it will reach full annual capacity of $38 \mathrm{bcm}$ by 2025 (Gazprom website, 2019). Another important event for Russia's gas industry happened in 2017 when the first train of the LNG plant with an annual production capacity of $5.5 \mathrm{mt}$ had been launched on the Yamal Peninsula. By the end of 2018 the LNG plant reached full annual capacity of $16.5 \mathrm{mt}$. The Yamal LNG project's major shareholder is Novatek (50.1\% of shares), French Total and Chinese CNPC have $20 \%$ of shares each, and Chinese Silk Road Foundation owns $9.9 \%$.

\subsection{Prospects for the Implementation of Russia's Gas Export Projects in Northeast Asia}

Two Russian gas companies (state company Gazprom and private company Novatek) carry out large-scale gas projects in the eastern part of Russia and in the Arctic, while there is a clear "division of labor" between them: the first one is mostly focused on pipeline gas, and the second deals only with LNG. Currently there are a number of Russia's gas projects (at different stages of implementation and planning) that are largely focused on NEA market: the Power of Siberia, the Power of Siberia-2 (the West Route), the Power of Siberia-3, the Power of Siberia Expansion, the Sakhalin-2 LNG, the third train of the Sakhalin-2 LNG (all - Gazprom); Yamal LNG, the Arctic LNG-1, the Arctic LNG-2, the Arctic LNG-3, Obskiy LNG (all - Novatek). In the subsection 3.2 the authors compare the strengths and weaknesses of these projects which, due to limited resources and other factors, in terms of implementation often represent an alternative to each other. To a greater extent this applies to projects of Gazprom.

\subsubsection{Power of Siberia Expansion VS. Power of Siberia-2}

According to the Chairman of Gazprom Alexei Miller, Chinese partners are interested to increase the volume of gas above what they would get by the terms of the Power of Siberia contract (more than $1000 \mathrm{cbm}$ in 30 years). He noted two (most feasible for Gazprom) gas pipeline projects to China that are under discussion: construction of the pipeline through the territory of Altai region (it is called the Power of Siberia-2 or "the West Route", and its planned annual gas supply volume is $30 \mathrm{bcm}$ ), and the Power of Siberia-3 pipeline (in December 2017 Gazprom and Chinese CNPC signed a preliminary agreement on conditions of gas supply from the RFE with an annual volume of $15 \mathrm{bcm}$ ) (Miller, 2019). At the same time, during a press-conference in Beijing President Putin reported that Chinese partners asked to consider the possibility of increasing supplies through the Power of Siberia pipeline, and, according to him, "technological capabilities allow it, and we will do it" (Putin, 2019).

President Putin was talking about the possible implementation of the so called Power of Siberia Expansion project (as the Power of Siberia-2, it is also supposed to provide a gas supply volume of $30 \mathrm{bcm}$ per year). This project is competing with the Power of Siberia-2. For Gazprom it is preferable to build the Power of Siberia-2 pipeline, the resource base for which will become already developed deposits of western Siberia. However the Power of Siberia Expansion project is preferable for Beijing due to lower transportation costs for gas delivery to consumption centers, and the lack of risk that Moscow will be able to become a swing supplier between European and Asian gas markets in the case that the Power of Siberia-2 project is implemented.

\subsubsection{Sakhalin-2 LNG third line VS. Power of Siberia-3}

According to the Memorandum signed in 2015 by Gazprom and Shell, an additional third train (with an annual capacity of $5.5 \mathrm{mt}$ ) should be built at the Sakhalin-2 LNG plant. To supply this additional train, Sakhalin-2 will require $8 \mathrm{bcm}$ of natural gas annually, while Gazprom considers to launch it in $2022-2023$. The third train of Sakhalin-2 LNG is competing with the Power of Siberia-3 - another Gazprom project to deliver gas to China by the Sakhalin-Khabarovsk-Vladivostok pipeline built in 2011. Presence of large gas deposits on Sakhalin and availability of the above mentioned gas transmission system (an off-shoot from this pipeline to the border with China will not exceed 45 kilometers) make the project a priority for Gazprom. For Beijing it is also beneficial due to a short distance for gas delivery and the arrival of the pipeline into industrial and densely populated provinces of northeastern China with predominantly coal power.

Besides, for a long time discussions were going on possible construction of gas pipelines from the Sakhalin Island to Japan and from Primorsky Krai in Russia to ROK via the DPRK territory. However, Gazprom considers a pipeline to Japan as an impractical solution from both economic and technological standpoints. Instead, it prefers to increase supply of LNG to Japan. As far as a gas pipeline to ROK, Gazprom is interested in principle, but its construction could become possible only after substantial improvement of security situation at the Korean Peninsula (Sevastyanov, 2017).

\subsubsection{Novatek LNG projects in the Arctic}

Hydrocarbon production and transportation can become the basis for complex development of the Northern Sea Route (NSR), while Yamal LNG became a pilot project for the development of the Russia's LNG-sector in the 
Arctic. This project has got a substantial support from the Russian government: for 12 years it is exempt from paying export duty and taxes on mining and property, while income tax has been reduced from $20 \%$ to $13,5 \%$. The state also took over the costs of building transportation and social infrastructure (Vedomosti.ru, 2014).

In December 2018 the Yamal LNG plant reached planned capacity of $16.5 \mathrm{mt}$, while in February 2019 the company has started construction of the fourth pilot train there of about a million tons that will use only Russian liquefaction technology and equipment (Kremlin Website, 2019). At the same time Novatek has started construction of the new LNG plant at the northern part of the Gydan Peninsula - Arctic LNG-2, with a planned capacity of $19.8 \mathrm{mt}$ per year. The phased launch of three trains (6.6 mt each) is scheduled for 2023-2025. In June 2019 Arctic LNG-2 shareholders were formed: major shareholder - Novatek (60\% of shares), French Total, Chinese companies CNODC (100\% subsidiary of CNPC) и CNOOC have acquired $10 \%$ each, and a consortium of Japanese companies Mitsui и JOGMEC got 10\% of shares (Novatek website, 2019).

Besides, Novatek announced plans to build another LNG plant of the same capacity of $19.8 \mathrm{mt}$ (three trains with a capacity of $6.6 \mathrm{mt}$ each), and thus by 2030 to achieve annual LNG production of $57 \mathrm{mt}$. However, Novatek's resource base allows it to produce more than $100 \mathrm{mt}$ of LNG per year, and the company is exploring the possibility of building two additional trains of standard capacity. This will allow the company to bring the total annual LNG production volume by 2030 to a very impressive $70 \mathrm{mt}$, "the size of Qatar's output today" (Downs, Henderson, Herberg, et. al, 2018). Except large-capacity LNG projects, Novatek announced a plan to build by 2023 a low-tonnage Obskiy LNG plant near the port of Sabetta on the Yamal Peninsula. Three trains of total annual capacity of $4.8 \mathrm{mt}$ are planned to be built based on "Arctic cascade" technology developed by Novatek (Ria.ru, 2019a).

\subsection{Sanctions' Impact on Gazprom and Novatek Development Strategies, and the Countermeasures They Have Taken}

In the first half of 2014 the US and the EU began to apply sanctions against Russia aimed at restricting access of major Russian banks and companies to Western financial resources, and at banning transfer of technologies and equipment to the defense industrial complex and oil and gas giants, such as Gazprom, Rosneft, Novatek, and the like. Since then those sectoral sanctions have been repeatedly supplemented, augmented and detailed (Coate, 2018).

Under the US sanctions, American companies are prohibited from provision of new financial debts of longer than 90 days for sanctioned Russian energy companies, and not allowed to provide equipment, services, or technology that support exploration or production for offshore operations in waters deeper than five hundred feet, Arctic offshore projects, etc. However, gas production growth in the eastern part of the RF has been secured by the Russian government's program of the accelerated import substitution, uneven application of sanctions by the U.S. and the EU, and by strong financial support from China. Starting from 2014 the RF government launched a large scale program of import substitution and substantial support of strategic industries with a special emphasis on financing projects contributing to the creation of new Russian technologies and equipment in oil and gas exploration, processing and transportation (Komkov, Bondareva, 2017).

To withstand Western sanctions Gazprom took an evasive approach toward gas offshore exploration in the Arctic and Sakhalin. In 2014 the company hoped to double its Arctic offshore reserves and to launch up to 12 new fields by 2024. But radical changes in the energy economics in 2014 (the plunge in oil prices, Western sanctions, shale gas revolution in the US, etc.) have fundamentally changed these plans (Russian Oil and Gas, 2017). Besides, gas is more accessible onshore, while Gazprom has licenses for the development of 37 gas fields in the eastern Siberia and the RFE with a total amount of reserves more than $5700 \mathrm{bcm}$. Thus, enjoying a monopoly over Russia's gas exports, Gazprom continues to prioritize pipeline projects, while during recent visit to China Miller made a clear focus on reaching an agreement on the construction of at least one more pipeline to this country.

Opposite to that, the private company Novatek, being from July 2014 under the American sanctions, didn't change intentions to realize the Yamal-LNG project, but was forced to correct financial plans. Being unable to attract funding from European and American banks, Russia had to: firstly, mobilize internal resources (in 2015 it was decided to allocate 150 billion rubles from the National Welfare Fund of Russia and to sign contracts with Sberbank and Gazprombank for 3.6 billion Euros credit for 15 years); secondly, more actively involve Chinese partners in the project (the sale of 29,9\% Novatek shares to Chinese companies, and receiving the loan of 12 billion USD from the Export-Import Bank of China and "China Development Bank Corp") (Sevastyanov, Kravchuk, 2017).

Completing the Yamal LNG project within budget and on time, Novatek gained high credibility with partners, 
contractors and customers, and therefore finalizing investment decision for the next project (the Arctic LNG-2) became easier for it. As far as foreign partners, Novatek used same model as for Yamal LNG. The first block of shares has been sold to Total, the largest portion has been acquired by Chinese companies, plus a new participant has been added (a consortium of two Japanese companies). Arctic LNG-2, as well as the previous Yamal LNG, would be realized in close cooperation with European and Asian contractors, many of which have been involved in both projects. To complete Yamal LNG Novatek signed contracts for the design and supply of equipment, materials and components with such foreign companies, as: "Technip" and "Vinci" (France), "Siemens" (Germany), "JGC Corp" (Japan), "COOEC" (China), and others. As far as Arctic LNG-2, Novatek also signed contracts with leading European and Asian companies in the field (see Note 1). In accordance with the Russian leadership task, Novatek is making serious efforts to build up own gas liquefying capacities and to localize equipment production. For example, the share of Russian orders in the Yamal LNG project amounted to 30\%, but for the Arctic-LNG-2 the RF Government has set the goal to achieve at least $70 \%$ localization of technologies and equipment (Vesti.ru, 2019). Obskiy LNG plant is planned as the first project to be realized based entirely on Russian liquefaction technology. The annual LNG output of one production train at this plant will be $1.6 \mathrm{mt}$ against $1 \mathrm{mt}$ of the Yamal LNG fourth train. Thus the capacity of the LNG trains is gradually increased by Novatek with the development of Russian technologies (Ria.ru, 2019a).

The Yamal LNG project cost was $\$ 27$ bln, while the Arctic LNG-2 project will cost around $\$ 20-21$ bln. Cost reduction will occur due to increase in the share of Russian liquefaction technologies and equipment, and through the use of innovative concepts. For example, Arctic LNG-2 liquefaction trains will be located not on the ground, but on the floating gravity-based platforms in the Ob Bay. The serial production of those trains, including gravity-based platforms and gas liquefaction modules, will be organized in the Center for construction of large-capacity marine structures to be built in Murmansk.

To reduce LNG transportation costs Novatek plans to build two floating LNG transshipment hubs: near the city of Murmansk by 2022 and another one in the Bechevinskaya bay on the Kamchatka Peninsula by 2023 with an annual productivity of $20 \mathrm{mt}$ and $21.7 \mathrm{mt}$ respectively. LNG hubs creation will provide Novatek with the flexibility to supply it worldwide, and increase efficiency of ice class gas carriers' exploitation through the NSR. Finally, In June 2019 Novatek and Gazprombank signed a legally binding agreement with Chinese petrochemical company Sinopec on formation of a joint venture to sell Russian LNG at China's domestic market. According to Mikhelson, this agreement guarantees Russian LNG sales in China and will open up opportunities for Novatek for the development of final consumption in this largest market (Ria.ru, 2019b).

\section{Discussion}

The results obtained allowed solving two key research tasks that have been formulated by the authors. Firstly, results of a comprehensive analysis of the gas projects that have been implemented by Novatek and Gazprom in the Arctic and in the eastern part of Russia demonstrated that being under Western sanctions both companies still were able to successfully execute them in time (Yamal LNG started in December 2018 and Power of Siberia - in December 2019). Besides, based on those results the authors were able to make predictive estimates of probable execution dates and gas production volumes for both companies' current and future projects till the year 2030 .

Secondly, the research results demonstrated that to withstand Western sanctions Gazprom and Novatek resorted to different strategies. As a part of it Gazprom has been forced to postpone plans for offshore gas exploration, while Novatek with the help of European and Asian partners was able to continue execution of its LNG projects in the Arctic (for more features of and differences between two companies' strategies see the Concluding section).

The results of the study also helped to define the main risks that Russia may encounter in implementing its strategy to increase gas exports to NEA:

- increased Western sanctions' pressure which can lead to financial and technological difficulties and, as a result, to a backlog or abandonment of gas projects;

- macroeconomic instability in Russia, which may lead to reduced state financial support for Arctic projects, reassessment by foreign investors of opportunities to enter Russian gas projects and difficulties in their implementation;

- reduced natural gas demand in NEA due to rapid development of alternative energy sources and increase in energy efficiency.

In this paper the authors made the main focus on studying the effects of the Western sanctions. Considering the macroeconomic situation in Russia, it is a topic of a special separate research; while in this work the authors 
made an assumption that overall it will remain stable, since so far they have no credible arguments to think otherwise.

The authors made a general estimate of NEA gas demand and accordingly of gas export growth prospects for Russia in the region based on study of demand in its key gas importers (China, Japan and RK). China's gas market specificity is determined by high rates of gas consumption and import growth. According to the consensus forecast, annual gas production in China is projected at $185.6 \mathrm{bcm}$ by 2020 and at $285.6 \mathrm{bcm}$ by 2030 (Link.springer.com, 2019). In this way gas annual imports by 2020 will be around $139.4 \mathrm{bcm}$, and by $2030-$ about $229.4 \mathrm{bcm}$. Gas consumption dynamics in Japan and RK are similar, and characterized by stagnation and slow decline due to increased energy efficiency and economic slowdown. In 2018, gas consumption in Japan has been $115.7 \mathrm{bcm}$, and in RK $-55.9 \mathrm{bcm}$. (Platts.com, 2019). Overall, the analysis has clarified that gas demand in NEA in the medium term will continue to grow substantially at the expense of China. By 2020 the volume of gas imports by the three countries will be around $311 \mathrm{bcm}$, by $2025-356 \mathrm{bcm}$, and by $2030-400 \mathrm{bcm}$.

As for the ability of countries to significantly increase gas exports to NEA in the medium term, the pipeline component will grow mainly due to Gazprom deliveries to China, the routes and volumes of which are actively discussed by Moscow and Beijing. In the LNG industry the situation is more dynamic, where four players (Australia, Qatar, USA and Russia) will dominate the global market as a result of the American and Russian exports' growth. Besides, we should take into account that though gas supplies from Russia are one of the safest ways for NEA countries' import, its total gas market share in the region in 2018 was a modest $4.51 \%$ (BP, 2019), thus Russian gas supplies' projected increase does not pose any threat to NEA energy security.

Based on the analysis of Gazprom and Novatek plans for the development of existing and future projects in the Arctic and the eastern part of Russia, and the above mentioned risks that Moscow may encounter, authors modeled three scenarios for the development of Russia's gas exports to NEA by 2030. Due to an assumption that macroeconomic situation in Russia will remain stable and a very positive estimate of the NEA gas demand growth, the authors tried to consider the situation with the scale and level of the Western economic sanctions against Russia as a key variable based on which those scenarios could have been modeled. However, though at first glance it might seem that the "state of the Western sanctions against Russia" variable could be easily changed, in reality current state of Russian - American relations (that are characterized by tough political contradictions, but also by the need for cooperation in solving global problems) actually is very hard to radically change in one direction or another.

The authors believe that under a pessimistic scenario, involving a significant increase in Western sanctions against Russia's energy industry, projects, previously started by Gazprom and Novatek, will be completed late, while new projects will not be launched. In this case Russian gas export to NEA will still grow, but not substantially. However, implementation of the pessimistic scenario in the future (given the contradictions in this regard between different branches of American power, and also between the U.S and several leading European and Asian countries) is hardly possible. Implementation of the optimistic scenario depends on the lifting of anti-Russian sanctions that could enable the rapid development of new offshore fields and simplify the attraction of foreign capital in gas projects. Given the weak prospects for substantial improvement in Russian - American relations, this is also not realistic.

Thus in this paper the authors make a forecast within the most probable baseline scenario that suggests the following conditions in the period up to 2030 will apply:

- anti-Russian sanctions remain at about the same level;

- China maintains a high growth rate of natural gas imports that is accompanied by a slight decrease in LNG purchases in Japan and RK;

- the macroeconomic situation in Russia will remain stable allowing state support of the gas projects in the form of limited tax benefits and investments in new technologies and infrastructure.

If these conditions are met, the authors believe that all projects planned by Gazprom and Novatek in the region will be fully implemented in terms of gas production and export volumes with possible delay from the announced deadlines due to a longer creation of gas resources' base and transportation infrastructure caused by Western sanctions (see Note 2).

\section{Conclusion}

In terms of the international political situation, the improving technological capabilities of Russian companies, and the need to meet the growing energy requirements of NEA countries, particularly China, the baseline scenario in the development of Russian gas exports to NEA may come true with high probability. Concerning the 
indicators of the RF Energy Strategy till 2035, Russian annual gas exports to NEA should be from 64 to $115 \mathrm{bcm}$. We suggest that the strategy's upper threshold matches the parameters of the baseline scenario, because, according to the authors' calculations and projections, the total export of Russian gas to NEA by 2030 may reach about $117 \mathrm{bcm}$ (this total export volume is calculated on the basis of Gazprom and Novatek projects' planned production volumes and their expected completion dates - see Section 3.2 and Note 2 respectively). Realization of the above mentioned large scale energy projects, which are the real symbols of regionalism, will strengthen regional energy security and also help Russia to improve economic and political relations with NEA countries (Sevastyanov, 2011).

To resist sanctions the Russian government launched a program of accelerated import substitution with an emphasis on financing projects that contribute to the creation of Russian technologies and equipment in oil and gas exploration, processing and transportation. As a result, overall, Western sanctions against Russia's energy industry only partially achieved their goals. On the one hand, they led to the cancellation or postponing of a number of costly and complicated projects for gas production, on the other hand, most of the previously started and planned gas projects were implemented. Besides, sanctions helped foreigners to gain access to Russian projects in the Arctic, while China definitely used the chance more than others. Two Japanese companies also joined the Arctic LNG-2 thus helping Novatek to increase its technological, financial and to some extent political opportunities to implement current and future projects in the region.

Under Western sanctions' pressure the state company Gazprom postponed grand plans for offshore gas exploration in the Arctic and on Sakhalin. It continues to prioritize pipelines over LNG projects and is getting ready to launch first ever pipeline gas deliveries to China by the Power of Siberia in December 2019. Future increases in supplies to China by the Power of Siberia Expansion and Power of Siberia-3 pipelines are economically beneficial for both countries and strategically acceptable for Beijing, which depends on pipeline gas imports from Turkmenistan. However, as monopoly buyers of Russian pipeline gas in the RFE, Chinese companies are not in a hurry to sign new contracts with Gazprom and are insisting on lower prices for gas. To guarantee a long term and stable supply of gas to China at reasonable prices, Gazprom should diversify its strategy in the RFE by opening its upstream projects to Chinese and other foreign companies, and by starting the long delayed LNG projects in the region.

In contrast to Gazprom, the private company Novatek successfully creates a powerful infrastructure for gas production and processing in the Arctic and for delivering LNG to Europe and the APR. It includes the construction of several LNG plants, a center for building large-capacity marine structures, two LNG transshipment hubs, etc. At the same time, the company has building up its gas liquefying capacities and localizing equipment production. Novatek was able, on the one hand, to perform advanced forms of upstream industrial cooperation with foreign partners in Yamal LNG and Arctic LNG-2 projects, and, on the other hand, to diversify partners' composition retaining the freedom of choice in planning and execution of LNG projects.

\section{Conflict of Interests}

The authors confirm that the data presented does not contain any conflict of interest.

\section{Acknowledgements}

This work was supported by the Russian Foundation for Basic Research (Scientific project \# 18-011-00032\19 "Development institutions as a tool for administration of transborder relations at the Russian Far East").

\section{References}

Adobe Reader Energy Strategy of the Russian Federation for the period up to 2035. (2015). Retrieved September 15, 2016, from http://www.energystrategy.ru/ab_ins/source/ES-2035_09_2015.pdf

Baev, P. (2015). Russia's Arctic illusions. Retrieved April 18, 2018, from http://www.brookings.edu/blog/order-from-chaos/2015/08/27/russias-arctic-illusions

Blank, S., \& Kim Y. (2014). US shale revolution and Russia: shifting geopolitics of energy in Europe and Asia. Asia Europe Journal, 13(1), 95-112. https://doi.org/10.1007/s10308-014-0404-z

BP Statistical Review of World Energy. (2019). Retrieved June 20, 2019, from https://www.bp.com/content/dam/bp/business-sites/en/global/corporate/pdfs/energy-economics/statistical-re view/bp-stats-review-2019-full-report.pdf

Coote, B. (2018). Impact of Sanctions on Russia's Energy Sector. Retrieved June 10, 2018, from https://www.atlanticcouncil.org/publications/reports/impact-of-sanctions-on-russia-s-energy-sector

Downs, E. et. al. (2018). The Emerging Russia - Asia Energy Nexus. NBR Special Report \# 74. Retrived from 
Special_report_74_emerging_russia-asia_energy_nexus_dec2018.pdf

Gazprom website. (2019). Retrieved April http://www.gazprom.ru/about/production/projects/pipelines/built/ykv

28, 2019, from

Kapyla, J., Mikkola, H., \& Martikainen, T. (2016). Moscow’s Arctic Dreams Turned Sour? FIIA Briefing Paper 192. Retrieved June $\quad 10, \quad 2016, \quad$ from https://www.fiia.fi/wp-content/uploads/2017/10/bp192_moscows-arctic-dreams-turned-sour.pdf

Komkov, N., \& Bondareva, N. (2017). Import substitution in Russia as a development factor in global challenges period of 2017-2019. Modernization, Innovation, Development, 8(4), 640-656. https://doi.org/10.18184/2079-4665.2017.8.4.640-656

Kremlin Website. (2019). Meeting with Novatek CEO Leonid Mikhelson. Retrieved March 1, 2019, from http://en.kremlin.ru/events/president/news/59894

$\begin{array}{lllll}\text { Link.springer.com. } & \text { (2019). } & \text { Retrieved } & \text { June } & \text { 5, 2019, }\end{array}$ https://link.springer.com/article/10.1007/s12182-016-0101-x\#CR5

Miller, A. (2019). Column of Alexey Miller. Retrieved May 5, 2019, from http://www.gazprom.ru/press/news/miller-journal

Motomura, M. (2014). Japan's need for Russian oil and gas: A shift in energy flows to the Far East. Energy Policy, 74, 68-79. http://doi.org/10.1016/j.enpol.2014.08.24

Ngv.ru. (2017). Russia increases oil export to Asia. Retrieved February 25, 2017, from http://www.ngv.ru/news/rossiya_narashchivaet_eksport_nefti_v_aziyu_reuters_/?sphrase_id $=9534977$

Novatek website. (2019). Retrieved May 15, 2019, from http://www.novatek.ru/ru/press/releases/index.php?id_4=3280

Platts.com. (2019). Retrieved $\quad$ June $15, \quad 2019, \quad$ from https://www.platts.com/latest-news/natural-gas/tokyo/japans-lng-imports-to-drop-by-one-third-to-62-27804 157

Putin, V. (2019). News conference following working visit to China. 27 April, Beijing. Retrieved April 28, 2019, from http://en.kremlin.ru/events/president/news/60396

Ria.Ru. (2019a). Arctic lokomotiv or tens of billions into new LNG capacity. Retrieved May 25, 2019, from https://ria.ru/20190523/1554816814.html

Ria.Ru. (2019b). Big Chinese exchange. PRC admits Russian LNG to its markets. Retrieved June 8, 2019, from https://ria.ru/20190607/1555335212.html

Russian Oil and Gas. (2017). Tomorrow is a Distant Memory. Sberbank CIB Investment Research. Oil and Gas. Retrieved January 20, 2019, from http://neftianka.ru/wp-content/uploads/2017/11/2_5467772892869558529.pdf.pdf

Sevastyanov, S. (2011). Noviye proekti aziatsko-tihookeanskoi intrgratcii (New Projects of the Asia-Pacific Integration). World Economy and International Relations, 1, 48-54.

Sevastyanov, S. (2017). Hopes and Realities in Relations between Russia \& Japan: Is a Breakthrough Possible? East Asia: An International Quarterly, 34(1), 39-62. https:// doi.org/10/1007/s12140-017-9268-Z

Sevastyanov, S., \& Kravchuk, A. (2017). The Russian Approach to National Security in the Arctic. The Korean Journal of Defense Analysis, 29(1), 131-149.

Shi, Z. (2015). Building Strong China - Russia Energy Strategic Partnership. China International Studies, 47-65.

Thebarentsobserver.com (2018). Foreigners take lead in planning Russia's second arctic LNG project. Retrieved January 30, 2018, from https://thebarentsobserver.com/en/industry-and-energy/2018/01/foreigners-take-lead-planning-russias-secon d-arctic-lng-project

Vatansever, A. (2017). Is Russia building too many pipelines? Explaining Russia's oil and gas export strategy. Energy Policy, (108), 1-11. https://doi.org/10.1016/j.enpol.2017.05.038

Vedomosti.ru. (2014). The state will not leave under sanctions. Retrieved October 2, 2014, from https:/www.vedomosti.ru/business/articles/2014/09/22/gosudarstvo-pod-sankciyami-ne-ostavit

Vesti.ru. (2019). Russia plans active development of LNG projects on the Yamal Peninsula. Retrieved January 30, 
2019, from https://www.vesti.ru/doc.html?id=3109000\&utm_source=yxnews\&utm_medium=desktopNotes

Note 1. The prime contractor became the leader in the field British TechnipFMC (formed in 2016 by merging French Technip and American FMC Technologies), with which the contract is signed for design, supply, construction and commissioning of the plant. A licensing agreement for the purchase of gas liquefaction technology has been signed with German company Linde AG. Besides, an agreement with German company Siemens has been signed for supply of compressor equipment for three gas liquefaction trains. It opens up prospects for localizing the production of the compressor equipment in the interest of creating an LNG technology center in Russia (Thebarentsobserver.com, 2018). Chinese companies will also get significant contracts to implement Arctic LNG-2 project.

Note 2. The authors' estimated forecast for Gazprom and Novatek projects' completion dates in the framework of the baseline scenario follows. Gazprom projects: the Power of Siberia pipeline will reach full capacity by 2027. A choice between the Power of Siberia-2 and the Power of Siberia Expansion projects will be made most likely in favor of the latter, while its full design capacity will be reached by 2035. Construction of the Sakhalin-2 LNG third train will start after the Power of Siberia project is finished, and that train will become operational not earlier that 2027. The Power of Siberia-3 project with an annual output of about $10 \mathrm{bcm}$ could be realized by 2023. Novatek projects: three trains of the Arctic LNG-2 will be launched in 2024-2026. Obskiy LNG plant will be launched in 2023-2024. Three trains of the Arctic LNG-1 or the Arctic LNG-3 will become operational by 2030.

\section{Copyrights}

Copyright for this article is retained by the author(s), with first publication rights granted to the journal.

This is an open-access article distributed under the terms and conditions of the Creative Commons Attribution license (http://creativecommons.org/licenses/by/4.0/). 